\title{
Dissecting the many genetic faces of schizophrenia
}

\author{
DAN RUJESCU and DAVID A. COLLIER
}

\begin{abstract}
Recent genome-wide association studies in schizophrenia have provided strongest evidence for association and this strengthened when the affected phenotype included bipolar disorder suggesting that genes may not always associate with operationalised diagnostic entities. Several further large Genome Wide Association (GWA) studies on schizophrenia are under way and identified and replicated further loci in well-powered cohorts. The last 2 years have also witnessed an explosion of interest in human Copy Number Variants (CNVs). Deletions recently identified in schizophrenia (1q21.1; 2p16.3; 15q11.2; 15q13.3) have also been most recently found in further neurodevelopmental diseases. Thus, a significant fraction of individuals with neurodevelopmental diseases including schizophrenia carry CNVs and many will be defined as "genomic disorders" in the coming years. These findings could represent a decisive step towards understanding the causes of this severe mental disorder as well as developing new potential treatments. There is new hope that these new avenues will help understanding the neurobiology of schizophrenia in more depth leading to the development of new innovative diagnostic tools and therapies as was the case after the discovery of rare APP and presenilin 1 and 2 mutations in Alzheimer's disease.
\end{abstract}

Declaration of Interest: None.

Family, twin and adoption studies demonstrate evidence for a strong genetic component in the aetiology of schizophrenia. The relative contribution of genetic factors to the etiology of schizophrenia has been estimated to be approximately $80 \%$. The mode of inheritance is complex and non-Mendelian, involving the combined action of several genes (Owen, 2005; Maier et al., 2005; Weinberger, 2005). The risk of developing the disease increases exponentially with the genetic relatedness to an individual suffering from the disorder. Third-degree relatives carry an approximate $2 \%$ chance of developing schizophrenia in comparison with the $1 \%$ risk for schizophrenia in the general population, and the risk increases to $9 \%$ in first-degree relatives. Moreover, in monozygotic (MZ) twins, the concordance rate is approximately $50 \%$. Adoption studies provide strong evidence that the familial aggregation is not the result of shared environmental factors, as because individuals adopted into families containing an affected individual do not have an increased risk of developing schizophrenia, whereas the

Address for correspondence: Professor Dan D. Rujescu, Head, Division of Molecular and Clinical Neurobiology, Department of Psychiatry, Ludwig-Maximilians-University, Nußbaumstr. 7, 80336 München (Germany).

Fax: +49-89-51605779

E-mail: Dan.Rujescu@med.uni-muenchen.de existence of a biological relative with schizophrenia does lead to an increased risk in adoptees. For schizophrenia, the number of susceptibility loci, the attributable risk conferred by each locus, and the degree of interaction between loci remain unknown. Till recently, two main approaches have been generally used in the search for susceptibility genes: linkage studies, which do not have to rely on specific biological hypotheses, seek to identify chromosomal regions containing susceptibility loci; and association studies, which are sensitive enough to detect small gene effects, but have to rely on plausible candidate genes (Owen et al., 2007; Norton et al., 2006).

Linkage studies are based on the fact that genetic variants located closely one to the other are more likely to be inherited together than genetic variants located further apart. First linkage studies in schizophrenia were driven by the assumption that genes of major effect can be identified, similar to the highly successful detection of genes with major effects in monogenic diseases. However, early positive findings were not replicated (Sherrington et al., 1998; Detera-Wadleigh et al., 1989), suggesting that highly penetrant mutations are rare (McGuffin et al., 1996). Nevertheless, moderately significant evidence for linkage has been found in more than one data set in several, unfortunately rather broad (often $>20-30 \mathrm{cM}$ ) chromosomal regions: 5q21-q31, 6p24-p22, 6q, 8p22-p21, 10p15-p11, 13q14.1-q32, and 22q11-q12 (Faraone et al., 1998; Schwab et al., 1997; 2003; Straub et al., 1997; 1998;

Epidemiologia e Psichiatria Sociale, 18, 2, 2009 
2002; Gill et al., 1996; Schizophrenia linkage collaborative group et al., 1996; Levinson, 2000; Lin et al., 1995; Blouin et al., 1998; Brzustowicz et al., 2000). The largest meta-analysis on linkage studies to date suggests several candidate chromosomal regions (1p13.3-q23.3; 2p12q22.1; 2q22.1-q23.3; 3p25.3-p22.1; 5q23.2-q34; 6pp22.3; 6p22.3-p21.1; 8p22-p21.1; 11q22.3-q24.1; 22pq12.3) for schizophrenia (Lewis et al., 2003). Thus, there is evidence implicating a number of chromosomal regions, which is consistent with the existence of multiple susceptibility genes of weak to moderate effect. Unfortunately, the methodology of linkage studies does not allow detecting the actual susceptibility genes of limited effect size, since the number of families required to localize these genes make these studies virtually impracticable.

Genetic association studies provide an alternative and powerful approach of identifying such genes in feasible sample sizes. These studies examine if genetic variants are associated with a certain trait or disorder. The simplest design compares the frequencies of genetic variants between groups of non-related cases and controls. Unfortunately, these studies have to rely on candidate genes derived from neurobiological research. Given that the pathophysiology of schizophrenia is far from being understood, genetic association studies had only limited success so far (Sanders et al., 2008).

The identification of genetic vulnerability factors should involve a comprehensive survey of the entire human genome. Developing tools such as high-density genetic maps for genome-wide association analyses has been the most important recent goal of the Human Genome Project. Recent progress in the field of parallel single nucleotide polymorphisms (SNPs) typing has made SNP-based genome screens an option. Recent genome-wide association studies have provided proof of principle and yielded several genes showing a strong association with complex diseases or traits including Chron's disease, diabetes, nicotine dependence and many others. O'Donovan et al. (2008b) carried out a genomewide association study of schizophrenia and replicated in up to 16,726 additional subjects. Of 12 loci followed up, 3 had strong independent support and the overall pattern of replication was unlikely to occur by chance. Metaanalysis provided strongest evidence for association around ZNF804A and this strengthened when the affected phenotype included bipolar disorder. This finding challenges the traditional diagnostic boundaries illustrating that genes may not always care about operationalized classification systems. Several further large GWA studies on schizophrenia are under way and identified and replicated further loci in well-powered cohorts. It will be of utmost interest to see if these new genes are also associated with bipolar disorder and other mental disorders.

There is a long lasting assumption in psychiatric genetics that common genetic variants with small effects are enhancing the risk to develop schizophrenia. Although debated for some time, the other side of the coin namely that rare genetic variations with large effects may account for a significant number of schizophrenia cases has been somehow neglected. However, rare variants with large effects on schizophrenia are known for a long time. One represents a private translocation in a Scottish family which disrupts DISC1. A more common deletion of chromosome 22q11 has also been repeatedly reported to substantially enhance the risk for developing schizophrenia. Over the last few years new genomic technologies, which can find gain or loss of genomic segments have made it possible to detect differences in DNA copy numbers at much higher resolution than cytogenetic methods, and have catalyzed an unparalleled era of discovery for clinical cytogenetics (for review see Cook \& Scherer, 2008; Ramocki \& Zoghbi, 2008; Slavotinek, 2008). A copy number variation (CNV) is a segment of DNA in which copy-number differences have been found. Humans usually have two copies of each autosomal region, one per chromosome. This may vary for particular genetic regions due to deletions or duplications.

Spontaneous (or inherited) copy number variations (CNVs) can therefore be identified in a hypothesis-free genome-wide approach. These techniques have shown that a much higher number of CNVs exists in humans than previously recognized. DNA arrays are of great help in finding de novo chromosome aberrations below the resolution of microscopy and give hope for the broad spectrum of neurodevelopmental disorders which appear to be made up from multiple rare disorders as the heterogeneity has in the past hampered traditional approaches for gene mapping. This type of structural chromosomal abnormalities is emerging as an important genomic cause of neuropsychiatric diseases, including mental retardation, autism and more recently schizophrenia. Walsh et al. (2008) investigated individuals with schizophrenia and controls in order to identify microdeletions and microduplications larger than 100.000 base pairs. Novel deletions and duplications of genes were present in 5\% of controls versus $15 \%$ of cases and $20 \%$ of young onset cases. These mutations in schizophrenia cases disrupted genes disproportionately from signalling networks controlling neurodevelopment, including neuregulin and glutamate pathways. The authors argue that these results suggest that multiple, individually rare mutations altering genes in neurodevelopmental pathways contribute to

Epidemiologia e Psichiatria Sociale, 18, 2, 2009 
schizophrenia. This study was only based on the data of a relatively small number of persons. In contrast, two newer studies were based on much larger sample sizes. These studies have successfully identified microdeletions associated with schizophrenia. In a genome-wide search for CNVs associating with schizophrenia performed by the SGENE consortium, a population based sample was used to identify de novo CNVs by analysing 9,878 transmissions from parents to offspring (Stefansson et al., 2008). The 66 de novo CNVs identified were tested for association in a sample of 1,433 schizophrenia cases and 33,250 controls. Three deletions at 1q21.1, 15q11.2 and $15 q 13.3$ showing nominal association with schizophrenia in the first sample (phase I) were followed up in a second sample of 3,285 cases and 7,951 controls (phase II). All three deletions significantly associate with schizophrenia and related psychoses in the combined sample. In a back to back paper, the International Schizophrenia Consortium reported a genome-wide survey of rare CNVs in 3,391 patients with schizophrenia and 3,181 controls (International Schizophrenia Consortium, 2008). For CNVs that were observed in less than $1 \%$ of the sample and were more than 100 kilobases in length, the total amount is increased 1.15-fold in patients with schizophrenia in comparison with controls. Associations with schizophrenia were also found for large deletions on chromosome 15q13.3 and 1q21.1. These findings could represent a decisive step towards understanding the causes of this severe mental disorder as well as developing new potential treatments. There is new hope that these new avenues will help understanding the neurobiology of schizophrenia in more depth leading to the development of new innovative diagnostic tools and therapies as was the case after the discovery of rare APP and presenilin 1 and 2 mutations in Alzheimer's disease.

Given that the above mentioned deletions recently found in psychosis (1q21.1;15q11.2;15q13.3 (Stefansson et al., 2008; International Schizophrenia Cconsortium, 2008) 2p16.3 (Kirov et al., 2008; Rujescu et al., 2008) have also been most recently identified in further neurodevelopmental diseases (including mental retardation (de Vries et al., 2005; Sharp et al., 2006; Murthy et al., 2007; Mefford et al., 2008), autism (Sebat et al., 2007; Abrahams \& Geschwind, 2008; Weiss et al., 2008) and seizures (Sharp et al., 2008); (for review see Cook \& Scherer, 2008; Ramocki \& Zoghbi, 2008; Slavotinek, 2008), it becomes evident that these carriers may present with a wide phenotypic spectrum. For example, the recently discovered de novo deletions on chromosome $15 q 13.3$ have been shown to give rise to a number of phenotypes, including minor dysmorphic features, abnormal
EEG, significant expressive language deficits, and a spectrum of neuropsychiatric impairments that include schizophrenia, autism spectrum disorder, ADHD, anxiety disorder, mood disorder and cognitive impairment varying from moderate mental retardation to normal IQ with learning disability (for review see St Clair, 2008; Cook \& Scherer, 2008; Ramocki \& Zoghbi, 2008; Slavotinek, 2008; O'Donovan et al., 2008a). Also the de novo 1q21.1 deletion has been associated with further phenotypes including mild-to-moderate mental retardation, microcephaly, cardiac abnormalities, and cataracts (Mefford et al., 2008; Walsh et al., 2008; Brunetti-Pierri et al., 2008).

Thus, the last 2 years have witnessed an explosion of interest in human CNVs. A significant fraction of individuals with neurodevelopmental diseases including schizophrenia carry CNVs and many will be defined as "genomic disorders" in the coming years. The discovery of CNV association with neurodevelopmental disorders has in turn raised a number of fascinating new clinical and scientific questions, especially concerning the phenotypic boundaries between major neurodevelopmental disorders as they are currently classified, their modes of inheritance, the implications of this new information for diagnostics and genetic counseling, the genetic and environmental factors that determine the penetrance and expressivity of $\mathrm{CNV}$-associated neurodevelopmental phenotypes, and finally the relationship between human behavior itself and human genomic evolution (St Clair, 2008; Cook \& Scherer, 2008; Ramocki \& Zoghbi, 2008; Slavotinek, 2008; O’Donovan et al., 2008a).

\section{REFERENCES}

Abrahams B.S. \& Geschwind D.H. (2008). Advances in autism genetics: on the threshold of a new neurobiology. Nature Review. Genetics 9, 341-355.

Blouin J.L., Dombroski B.A., Nath S.K., Lasseter V.K., Wolyniec P.S., Nestadt G., Thornquist M., Ullrich G., McGrath J., Kasch L., Lamacz M., Thomas M.G., Gehrig C., Radhakrishna U., Snyder S.E., Balk K.G., Neufeld K., Swartz K.L., DeMarchi N., Papadimitriou G.N., Dikeos D.G., Stefanis C.N., Chakravarti A., Childs B., Housman D.E., Kazazian H.H., Antonarakis S. \& Pulver A.E. (1998). Schizophrenia susceptibility loci on chromosomes $13 \mathrm{q} 32$ and 8p21. Nature Genetics 20, 70-73.

Brunetti-Pierri N., Berg J.S., Scaglia F., Belmont J., Bacino C.A., Sahoo T., Lalani S.R., Graham B., Lee B., Shinawi M., Shen J., Kang S.H., Pursley A., Lotze T., Kennedy G., Lansky-Shafer S., Weaver C., Roeder E.R., Grebe T.A., Arnold G.L., Hutchison T., Reimschisel T., Amato S., Geragthy M.T., Innis J.W., Obersztyn E., Nowakowska B., Rosengren S.S., Bader P.I., Grange D.K., Naqvi S., Garnica A.D., Bernes S.M., Fong C.T., Summers A., Walters W.D., Lupski J.R., Stankiewicz P., Cheung S.W. \& Patel A. (2008). Recurrent reciprocal 1q21.1 deletions and duplications associated with microcephaly or macrocephaly and developmental and behavioral abnormalities. Nature Genetics Epub 2008 Nov. 
Brzustowicz L.M., Hodgkinson K.A., Chow E.W., Honer W.G. \& Bassett A.S. (2000). Location of a major susceptibility locus for familial schizophrenia on chromosome 1q21-q22. Science 288(5466), 678-682.

Cook E.H., Jr. \& Scherer S.W. (2008). Copy-number variations associated with neuropsychiatric conditions. Nature 455(7215), 919-923.

de Vries B.B., Pfundt R., Leisink M., Koolen D.A., Vissers L.E., Janssen I.M., Reijmersdal S., Nillesen W.M., Huys E.H., Leeuw N., Smeets D., Sistermans E.A., Feuth T., Ravenswaaij-Arts C.M., van Kessel A.G., Schoenmakers E.F., Brunner H.G. \& Veltman J.A. (2005). Diagnostic genome profiling in mental retardation. American Journal of Human Genetics 77, 606-616.

Detera-Wadleigh S.D., Goldin L.R., Sherrington R., Encio I., de Miguel C., Berrettini W., Gurling H. \& Gershon E.S. (1989). Exclusion of linkage to 5q11-13 in families with schizophrenia and other psychiatric disorders. Nature 340(6232), 391-393.

Faraone S.V., Matise T., Svrakic D., Pepple J., Malaspina D., Suarez B., Hampe C., Zambuto C.T., Schmitt K., Meyer J., Markel P., Lee H., Harkavy Friedman J., Kaufmann C., Cloninger C.R. \& Tsuang M.T. (1998). Genome scan of European-American schizophrenia pedigrees: results of the NIMH Genetics Initiative and Millennium Consortium. American Journal of Medical Genetics 10, 81, 290-295.

Gill M., Vallada H., Collier D., Sham P., Holmans P., Murray R., McGuffin P., Nanko S., Owen M., Antonarakis S., Housman D., Kazazian H., Nestadt G., Pulver A.E., Straub R.E., MacLean C.J., Walsh D., Kendler K.S., DeLisi L., Polymeropoulos M., Coon H., Byerley W., Lofthouse R., Gershon E., Read C.M. et al. (1996). A combined analysis of D22S278 marker alleles in affected sib-pairs: support for a susceptibility locus for schizophrenia at chromosome 22q12. Schizophrenia Collaborative Linkage Group (Chromosome 22). American Journal of Medical Genetics 16, 67, 40-45.

International Schizophrenia Consortium (2008). Rare chromosomal deletions and duplications increase risk of schizophrenia. Nature. 455(7210), 237-241.

Kirov G., Gumus D., Chen W., Norton N., Georgieva L., Sari M., O’Donovan M.C., Erdogan F., Owen M.J., Ropers H.H. \& Ullmann R. (2008). Comparative genome hybridization suggests a role for NRXN1 and APBA2 in schizophrenia. Human Molecular Genetics $17,458-465$

Levinson D.F., Holmans P., Straub R.E., Owen M.J., Wildenauer D.B., Gejman P.V., Pulver A.E., Laurent C., Kendler K.S., Walsh D., Norton N., Williams N.M., Schwab S.G., Lerer B., Mowry B.J., Sanders A.R., Antonarakis S.E., Blouin J.L., DeLeuze J.F. \& Mallet J. (2000). Multicenter linkage study of schizophrenia candidate regions on chromosomes 5q, 6q, 10p, and 13q: schizophrenia linkage collaborative group III. American Journal of Medical Genetics 67, 652-663.

Lewis C.M., Levinson D.F., Wise L.H., DeLisi L.E., Straub R.E., Hovatta I., Williams N.M., Schwab S.G., Pulver A.E., Faraone S.V., Brzustowicz L.M., Kaufmann C.A., Garver D.L., Gurling H.M., Lindholm E., Coon H., Moises H.W., Byerley W., Shaw S.H., Mesen A., Sherrington R., O’Neill F.A., Walsh D., Kendler K.S., Ekelund J., Paunio T., Lonnqvist J., Peltonen L., O’Donovan M.C., Owen M.J., Wildenauer D.B., Maier W., Nestadt G., Blouin J.L., Antonarakis S.E., Mowry B.J., Silverman J.M., Crowe R.R., Cloninger C.R., Tsuang M.T., Malaspina D., Harkavy-Friedman J.M., Svrakic D.M., Bassett A.S., Holcomb J., Kalsi G., McQuillin A., Brynjolfson J., Sigmundsson T., Petursson H., Jazin E., Zoega T. \& Helgason T. (2003). Genome scan meta-analysis of schizophrenia and bipolar disorder, part II: Schizophrenia. American Journal of Medical Genetics 73, 34-48.

Lin M.W., Curtis D., Williams N., Arranz M., Nanko S., Collier D., McGuffin P., Murray R., Owen M., Gill M., et al. (1995). Suggestive evidence for linkage of schizophrenia to markers on chromosome 13q14.1-q32. Psychiatric Genetics 5(3), 117-26. Erratum in: Psychiatric Genetics 1996 Spring 6(1), 37.

Maier W., Hofgen B., Zobel A. \& Rietschel M. (2005). Genetic models of schizophrenia and bipolar disorder: overlapping inheritance or discrete genotypes? European Archives of Psychiatry and Clinical Neuroscience 255, 159-166.
McGuffin P. \& Owen M.J. (1996). Molecular genetic studies of schizophrenia. Cold Spring Harbor Symposia on Quantitative Biology $61,815-822$.

Mefford H.C., Sharp A.J., Baker C., Itsara A., Jiang Z., Buysse K., Huang S., Maloney V.K., Crolla J.A., Baralle D., Collins A., Mercer C., Norga K., de Ravel T., Devriendt K., Bongers E.M., de Leeuw N., Reardon W., Gimelli S., Bena F., Hennekam R.C., Male A., Gaunt L., Clayton-Smith J., Simonic I., Park S.M., Mehta S.G., Nik-Zainal S., Woods C.G., Firth H.V., Parkin G., Fichera M., Reitano S., Lo G.M., Li K.E., Casuga I., Broomer A., Conrad B., Schwerzmann M., Raber L., Gallati S., Striano P., Coppola A., Tolmie J.L., Tobias E.S., Lilley C., Armengol L., Spysschaert Y., Verloo P., De Coene A., Goossens L., Mortier G., Speleman F., van Binsbergen E., Nelen M.R., Hochstenbach R., Poot M., Gallagher L., Gill M., McClellan J., King M.C., Regan R., Skinner C., Stevenson R.E., Antonarakis S.E., Chen C., Estivill X., Menten B., Gimelli G., Gribble S., Schwartz S., Sutcliffe J.S., Walsh T., Knight S.J., Sebat J., Romano C., Schwartz C.E., Veltman J.A., de Vries B.B., Vermeesch J.R., Barber J.C., Willatt L., Tassabehji M. \& Eichler E.E. (2008) .Recurrent rearrangements of chromosome 1q21.1 and variable pediatric phenotypes. New England Journal of Medicine 359, 1685-1699.

Murthy S.K., Nygren A.O., El Shakankiry H.M., Schouten J.P., Al Khayat A.I., Ridha A. \& Al Ali M.T. (2007). Detection of a novel familial deletion of four genes between BP1 and BP2 of the PraderWilli/Angelman syndrome critical region by oligo-array CGH in a child with neurological disorder and speech impairment. Cytogenetic and Genome Research 116, 135-140.

Norton N., Williams H.J. \& Owen M.J. (2006). An update on the genetics of schizophrenia. Current Opinion in Psychiatry 19, 158-164.

O’Donovan M.C., Kirov G. \& Owen M.J. (2008a). Phenotypic variations on the theme of CNVs. Nature Genetics 40, 1392-1393.

O’Donovan M.C., Craddock N., Norton N., Williams H., Peirce T., Moskvina V., Nikolov I., Hamshere M., Carroll L., Georgieva L., Dwyer S., Holmans P., Marchini J.L., Spencer C.C., Howie B., Leung H.T., Hartmann A.M., Möller H.J., Morris D.W., Shi Y., Feng G., Hoffmann P., Propping P., Vasilescu C., Maier W., Rietschel M., Zammit S., Schumacher J., Quinn E.M., Schulze T.G., Williams N.M., Giegling I., Iwata N., Ikeda M., Darvasi A., Shifman S., He L., Duan J., Sanders A.R., Levinson D.F., Gejman P.V., Cichon S., Nöthen M.M., Gill M., Corvin A., Rujescu D., Kirov G., Owen M.J., Buccola N.G., Mowry B.J., Freedman R., Amin F., Black D.W., Silverman J.M., Byerley W.F., Cloninger C.R. \& Molecular Genetics of Schizophrenia Collaboration (2008b). Identification of loci associated with schizophrenia by genome-wide association and follow-up. Nature Genetics 40, 1053-1055.

Owen M.J. (2005) .Genomic approaches to schizophrenia. Clinical Therapy 27, Suppl. A, S2-7.

Owen M.J., Craddock N. \& Jablensky A. (2007). The genetic deconstruction of psychosis. Schizophrenia Bulletin 33, 905-911.

Ramocki M.B. \& Zoghbi H.Y. (2008). Failure of neuronal homeostasis results in common neuropsychiatric phenotypes. Nature 455(7215), 912-918.

Rujescu D., Ingason A., Cichon S., Pietilainen O.P., Barnes M.R., Toulopoulou T., Picchioni M., Vassos E., Ettinger U., Bramon E., Murray R., Ruggeri M., Tosato S., Bonetto C., Steinberg S., Sigurdsson E., Sigmundsson T., Petursson H., Gylfason A., Olason P.I., Hardarsson G., Jonsdottir G.A., Gustafsson O., Fossdal R., Giegling I., Moller H.J., Hartmann A., Hoffmann P., Crombie C., Fraser G., Walker N., Lonnqvist J., Suvisaari J., Tuulio-Henriksson A., Andreassen O.A., Djurovic S., Hansen T., Werge T., Melle I., Kiemeney L.A., Franke B., Buizer-Voskamp J.E., Ophoff R.A., Rietschel M., Nothen M.M., Stefansson K., Peltonen L., St Clair D., Stefansson H. \& Collier D.A. (2008). Disruption of the neurexin 1 gene is associated with schizophrenia. Human Molecular Genetics, Epub 2008 Oct.

Sanders A.R., Duan J., Levinson D.F., Shi J., He D., Hou C., Burrell G.J., Rice J.P., Nertney D.A., Olincy A., Rozic P., Vinogradov S., Buccola N.G., Mowry B.J., Freedman R., Amin F., Black D.W., 
Silverman J.M., Byerley W.F., Crowe R.R., Cloninger C.R., Martinez M. \& Gejman P.V. (2008). No significant association of 14 candidate genes with schizophrenia in a large European ancestry sample: implications for psychiatric genetics. American Journal of Psychiatry 165, $497-$ 506. Erratum in: American Journal of Psychiatry 165, 1359.

Schizophrenia linkage collaborative group (1996). Additional support for schizophrenia linkage on chromosomes 6 and 8: a multicenter study. Schizophrenia Linkage Collaborative Group for Chromosomes 3 , 6 and 8. American Journal of Medical Genetics 22;67, 580-594.

Schwab S.G., Eckstein G.N., Hallmayer J., Lerer B., Albus M., Borrmann M., Lichtermann D., Ertl M.A., Maier W. \& Wildenauer D.B. (1997). Evidence suggestive of a locus on chromosome 5q31 contributing to susceptibility for schizophrenia in German and Israeli families by multipoint affected sib-pair linkage analysis. Molecular Psychiatry 2, 156-160.

Schwab S.G., Knapp M., Mondabon S., Hallmayer J., BorrmannHassenbach M., Albus M., Lerer B., Rietschel M., Trixler M., Maier W. \& Wildenauer D.B. (2003). Support for association of schizophrenia with genetic variation in the 6p22.3 gene, dysbindin, in sib-pair families with linkage and in an additional sample of triad families. American Journal of Human Genetics 72, 185-190.

Sebat J., Lakshmi B., Malhotra D., Troge J., Lese-Martin C., Walsh T., Yamrom B., Yoon S., Krasnitz A., Kendall J., Leotta A., Pai D., Zhang R., Lee Y.H., Hicks J., Spence S.J., Lee A.T., Puura K., Lehtimaki T., Ledbetter D., Gregersen P.K., Bregman J., Sutcliffe J.S., Jobanputra V., Chung W., Warburton D., King M.C., Skuse D., Geschwind D.H., Gilliam T.C., Ye K. \& Wigler M. (2007). Strong association of de novo copy number mutations with autism. Science 316(5823), 445-449.

Sharp A.J., Hansen S., Selzer R.R., Cheng Z., Regan R., Hurst J.A., Stewart H., Price S.M., Blair E., Hennekam R.C., Fitzpatrick C.A., Segraves R., Richmond T.A., Guiver C., Albertson D.G., Pinkel D., Eis P.S., Schwartz S., Knight S.J. \& Eichler E.E. (2006). Discovery of previously unidentified genomic disorders from the duplication architecture of the human genome. Nature Genetics 38,1038-1042.

Sharp A.J., Mefford H.C., Li K., Baker C., Skinner C., Stevenson R.E., Schroer R.J., Novara F., De Gregori M., Ciccone R., Broomer A., Casuga I., Wang Y., Xiao C., Barbacioru C., Gimelli G., Bernardina B.D., Torniero C., Giorda R., Regan R., Murday V., Mansour S., Fichera M., Castiglia L., Failla P., Ventura M., Jiang Z., Cooper G.M., Knight S.J., Romano C., Zuffardi O., Chen C., Schwartz C.E. \& Eichler E.E. (2008). A recurrent 15q13.3 microdeletion syndrome associated with mental retardation and seizures. Nature Genetics 40, 322-328.

Sherrington P.D., Nacheva E., Fischer P., Rees J.K., Hoyle C., Dyer M., Harper P., Knight C. \& Hayhoe F.G. (1988). Translocation 5;21 and interstitial deletion of chromosome 7 in a case of chronic myelomonocytic leukemia. Cancer Genetics and Cytogenetics 31, 247-252.

Slavotinek A.M. (2008). Novel microdeletion syndromes detected by chromosome microarrays. Human Genetics 124, 1-17.
St Clair D. (2008). Copy number variation and schizophrenia. Schizophrenia Bulletin Epub 2008 Nov.

Stefansson H., Rujescu D., Cichon S., Pietilainen O.P., Ingason A., Steinberg S., Fossdal R., Sigurdsson E., Sigmundsson T., BuizerVoskamp J.E., Hansen T., Jakobsen K.D., Muglia P., Francks C., Matthews P.M., Gylfason A., Halldorsson B.V., Gudbjartsson D., Thorgeirsson T.E., Sigurdsson A., Jonasdottir A., Jonasdottir A., Bjornsson A., Mattiasdottir S., Blondal T., Haraldsson M., Magnusdottir B.B., Giegling I., Moller H.J., Hartmann A., Shianna K.V., Ge D., Need A.C., Crombie C., Fraser G., Walker N., Lonnqvist J., Suvisaari J., Tuulio-Henriksson A., Paunio T., Toulopoulou T., Bramon E., Di Forti M., Murray R., Ruggeri M., Vassos E., Tosato S., Walshe M., Li T., Vasilescu C., Muhleisen T.W., Wang A.G., Ullum H., Djurovic S., Melle I., Olesen J., Kiemeney L.A., Franke B., Sabatti C., Freimer N.B., Gulcher J.R., Thorsteinsdottir U., Kong A., Andreassen O.A., Ophoff R.A., Georgi A., Rietschel M., Werge T., Petursson H., Goldstein D.B., Nothen M.M., Peltonen L., Collier D.A., St Clair D. \& Stefansson K. (2008). Large recurrent microdeletions associated with schizophrenia. Nature 455(7210), 232-236.

Straub R.E., MacLean C.J., O’Neill F.A., Walsh D. \& Kendler K.S. (1997). Support for a possible schizophrenia vulnerability locus in region 5q22-31 in Irish families. Molecular Psychiatry 2, 148-155.

Straub R.E., MacLean C.J., Martin R.B., Ma Y., Myakishev M.V., Harris-Kerr C., Webb B.T., O'Neill F.A., Walsh D. \& Kendler K.S. (1998). A schizophrenia locus may be located in region 10p15-p11. American Journal of Medical Genetics 81, 296-301.

Straub R.E., Jiang Y., MacLean C.J., Ma Y., Webb B.T., Myakishev M.V., Harris-Kerr C., Wormley B., Sadek H., Kadambi B., Cesare A.J., Gibberman A., Wang X., O'Neill F.A., Walsh D. \& Kendler K.S. (2002). Genetic variation in the 6p22.3 gene DTNBP1, the human ortholog of the mouse dysbindin gene, is associated with schizophrenia. American Journal of Human Genetics 71, 337-348.

Walsh T., McClellan J.M., McCarthy S.E., Addington A.M., Pierce S.B., Cooper G.M., Nord A.S., Kusenda M., Malhotra D., Bhandari A., Stray S.M., Rippey C.F., Roccanova P., Makarov V., Lakshmi B., Findling R.L., Sikich L., Stromberg T., Merriman B., Gogtay N., Butler P., Eckstrand K., Noory L., Gochman P., Long R., Chen Z., Davis S., Baker C., Eichler E.E., Meltzer P.S., Nelson S.F., Singleton A.B., Lee M.K., Rapoport J.L., King M.C. \& Sebat J. (2008). Rare structural variants disrupt multiple genes in neurodevelopmental pathways in schizophrenia. Science 320(5875), 539-543.

Weinberger D.R. (2005). Genetic mechanisms of psychosis: in vivo and postmortem genomics. Clinical Therapy 27, Suppl A, S8-15.

Weiss L.A., Shen Y., Korn J.M., Arking D.E., Miller D.T., Fossdal R., Saemundsen E., Stefansson H., Ferreira M.A., Green T., Platt O.S., Ruderfer D.M., Walsh C.A., Altshuler D., Chakravarti A., Tanzi R.E., Stefansson K., Santangelo S.L., Gusella J.F., Sklar P., Wu B.L. \& Daly M.J. (2008). Association between microdeletion and microduplication at 16p11.2 and autism. New England Journal of Medicine 358, 667-675. 